\title{
Health Literacy in The Emergency Department: A Cross-sectional Descriptive Study
}

\author{
(1) Serdar Özdemir, (1) Hatice Șeyma Akça, (1) Abdullah Algın, (1) Kamil Kokulu
}

Clinic of Emergency Medicine, University of Health Sciences Turkey, Ümraniye Training and Research Hospital, İstanbul, Turkey

\begin{abstract}
Aim: In this study, we aimed to determine the health literacy level of the patients admitted to the emergency department with green triage code and discuss this in the light of current literature.

Materials and Methods: This cross-sectional descriptive-analytical study was performed on 285 subjects attending a tertiary hospital emergency department with green triage codes through convenience sampling method in 2019. Turkey Health Literacy scale-32 was used to collect data.

Results: One hundred two participants aged 18-83 years were included in the study. Health literacy indexes of the participants ranged between 11.67 and 48.44 and the mean value was calculated as 30.9 (poor). The Health Literacy index of 59 (57.9\%) participants was considered to be poor.

Conclusion: In our study, health literacy levels of patients who applied to emergency department with green triage code were found to be poor. More attention to health promotion programs and health education is needed.
\end{abstract}

Keywords: Emergency department, health literacy, health knowledge, patient education

\section{Introduction}

Health literacy, evaluates the skills of reading of health information and tables, using instruments related to personal and family health, calculation of drug timing and dosage, participating in research studies, and commenting on health and environmental policies. Health literacy levels vary according to language, culture, cultural and social environment, education system and education level and the relationship of the society in which they live with health (1).

Health literacy is an important concept for health promotion, disease prevention and early recognition and policy development in this area. Low health literacy level is associated with less access to preventive health services and the use of emergency services for health care (2). Low health literacy results in non-use of preventive health services, inability to understand one's health and to follow health instructions. However, increasing health costs are inevitable (3).
Emergency services are an entry point for access to the health system of patients with acute illnesses and in need of emergency medical treatment (4). Attempting to eliminate the health problems that can be treated in primary health care institutions in the emergency department is an additional burden on emergency services $(4,5)$. Although it is not the only reason for non-emergency patients to use the emergency service, socioeconomic reasons are also effective $(4,5)$.

In this study, we aimed to determine the health literacy level of the patients admitted to the emergency department with green triage code and discuss this in the light of current literature. Our secondary aim was to reveal the relationship between health literacy and demographic data of patients who applied to emergency department with green triage code.

\section{Materials and Methods}

The ethical committee approval of our study was obtained from 
the Ethical Committee of Clinic Researches of İstanbul Ümraniye Training and Research Hospital (approval number: 2018/153).

\section{Study Population and Data Collection}

In this study, health literacy levels of patients who were admitted to a tertiary hospital emergency department with green triage codes and agree to participate in the study were evaluated. Those who agreed to participate in the study and who had a green triage code were included in the study. Workers in healthrelated professions were excluded from the study.

To ensure random sampling, each twentieth patients following the first randomly selected patient were offered to participate in a study. Sampling was performed every day of the week and every hour of the day in order to increase the representation of the working group.

The patients were given preliminary information about the study and offered to participate in the study. Those who agreed to participate in the study were given an informed consent form and were asked to sign it. The interview with the research participants was conducted by an educated research assistant who read the questionnaire questions and answer options in the emergency room waiting room.

Health literacy levels and demographic characteristics of the participants such as age, gender, marital status, occupation, income and educational status were evaluated. Participants were grouped according to their educational status as primary and non-educated, secondary, high school, university and above; according to their professions as housewives, students, retirees, artisans, workers, freelancers, farmers and others; according to their financial status as income less than expense, income equivalent and income more than expense.

Participants' health literacy levels were determined using the Turkey Health Literacy scale-32. Health related professionals were not included in the study. In the evaluation of the scale; The indexes are standardized to be between 0 and 50 as in the HLS-EU study (1). For this purpose [index=(mean-1) x (50/3)] formula is used.

\section{Statistical Analysis}

Categorical data were expressed as number and percentage, and numerical data were expressed as median, minimum and maximum. Shapiro-Wilk test was used to evaluate the distribution pattern of numerical data. SPSS 21.0 (IBM Corp., Armonk, NY, USA) software was used for statistical analysis. Mann-Whitney U test was used to compare age and literacy index with gender and marital status, and Kruskal-Wallis test was used to compare education level, occupational group and income status. In Kruskal-Wallis test, the results of the paired comparison analyzes were evaluated in order to determine which groups were statistically significant. Spearman correlation was used to compare age and Health Literacy index.

\section{Results}

One hundred twenty-nine patients agreed to participate in the study. Twenty-seven participants were excluded from the study because of working in health-related occupations. One hundred two participants were included in the study. The ages of the participants ranged from 18 to 83 years with a median of 36 years. Descriptive statistical data regarding the categorical data of the subjects included in the study are summarized in Table 1.

Health literacy indexes of the participants ranged between 11.67 and 48.44 and the mean value was calculated as 30.9 (poor). The Health Literacy index of 59 (57.9\%) participants was poor (below 33).

Table 1. The categorical data of the subjects included in the study

\begin{tabular}{|l|l|l|}
\hline $\mathbf{n = 1 0 2}$ & $\mathbf{n}$ & $\%$ \\
\hline Gender & 47 & 46.1 \\
\hline Male & 55 & 53.9 \\
\hline Female & \multicolumn{3}{|l}{} \\
\hline Marital status & 54 & 52.9 \\
\hline Married & 48 & 47.1 \\
\hline Single & &
\end{tabular}

Educational status

\begin{tabular}{|l|l|l|}
\hline Primary and non-educated & 27 & 26.5 \\
\hline Secondary school & 18 & 17.6 \\
\hline High school & 40 & 39.2 \\
\hline University and above & 4 & 16.7 \\
\hline
\end{tabular}

\begin{tabular}{|l|l|l|}
\hline Professions & 24 & 23.5 \\
\hline Housewives & 20 & 19.6 \\
\hline Students & 5 & 4.9 \\
\hline Retirees & 22 & 21.6 \\
\hline Artisans & 7 & 6.9 \\
\hline Workers & 6 & 5.9 \\
\hline Freelancers & 6 & 5.9 \\
\hline Farmers & 12 & 11.8 \\
\hline Others & \multicolumn{2}{|l|}{} \\
\hline Financial status & 22 & 21.6 \\
\hline Income less than expense & 63 & 61.8 \\
\hline Income equivalent & 17 & 16.7 \\
\hline Income more than expense & \multicolumn{2}{|l}{} \\
\hline n: Number & \multicolumn{3}{|l}{} \\
\hline
\end{tabular}


Data on the comparison of Health Literacy index and categorical data are shown in Table 2.

There was a statistically significant, negative and weak correlation between Health Literacy index and age. (Spearman correlation test, $r=-0.254, p=0.01$ ). The scatter graph of the correlation analysis is shown in graph 1.

When the relationship between Health Literacy index and education levels was investigated, a statistically significant difference was found between the secondary and high school graduates in the paired comparison $(p=0.017)$. The difference between the other groups was not statistically significant. Adjusted $p$ values were 0.178 between secondary school and university, but it was 1 in all other binary comparisons.

\section{Discussion}

The concept of health literacy includes some skills necessary for the maintenance of health. In addition to the ability to find,

\begin{tabular}{|c|c|c|}
\hline$n=102$ & $\begin{array}{l}\text { Median (minimum- } \\
\text { maximum) }\end{array}$ & p \\
\hline \multicolumn{3}{|l|}{ Gender } \\
\hline Male & $30.87(14.37-45.83)$ & \multirow[t]{2}{*}{$0.92^{*}$} \\
\hline Female & $31.38(14.37-45.83)$ & \\
\hline \multicolumn{3}{|l|}{ Marital status } \\
\hline Married & $30.59(11.67-45.83)$ & \multirow[t]{2}{*}{$0.133^{*}$} \\
\hline Single & $33.13(14.67-48.44)$ & \\
\hline \multicolumn{3}{|l|}{ Educational status } \\
\hline Primary and non-educated & $30.33(11.67-44.87)$ & \multirow{4}{*}{$0.031^{* *}$} \\
\hline Secondary school & $27.88(14.37-36.54)$ & \\
\hline High school & $33.13(17.26-48.44)$ & \\
\hline University and above & $35.02(28.33-38.17)$ & \\
\hline \multicolumn{3}{|l|}{ Professions } \\
\hline Housewives & 30.61 (11.67-44.87) & \multirow{8}{*}{$0.037^{* * *}$} \\
\hline Students & $29.22(17.19-42.19)$ & \\
\hline Retirees & $23.09(14.37-40.1)$ & \\
\hline Artisans & $34.24(17.26-48.44)$ & \\
\hline Workers & $35.54(29.17-45.83)$ & \\
\hline Freelancers & $33.17(30.21-43.23)$ & \\
\hline Farmers & $29.29(31.25-40.86)$ & \\
\hline Others & $34.64(28.33-43.23)$ & \\
\hline \multicolumn{3}{|l|}{ Financial status } \\
\hline Income less than expense & $30.89(17.39-45.4)$ & \multirow{3}{*}{$0.898 * *$} \\
\hline Income equivalent & $31.38(11.67-48.44)$ & \\
\hline Income more than expense & $30.89(19.35-45)$ & \\
\hline
\end{tabular}

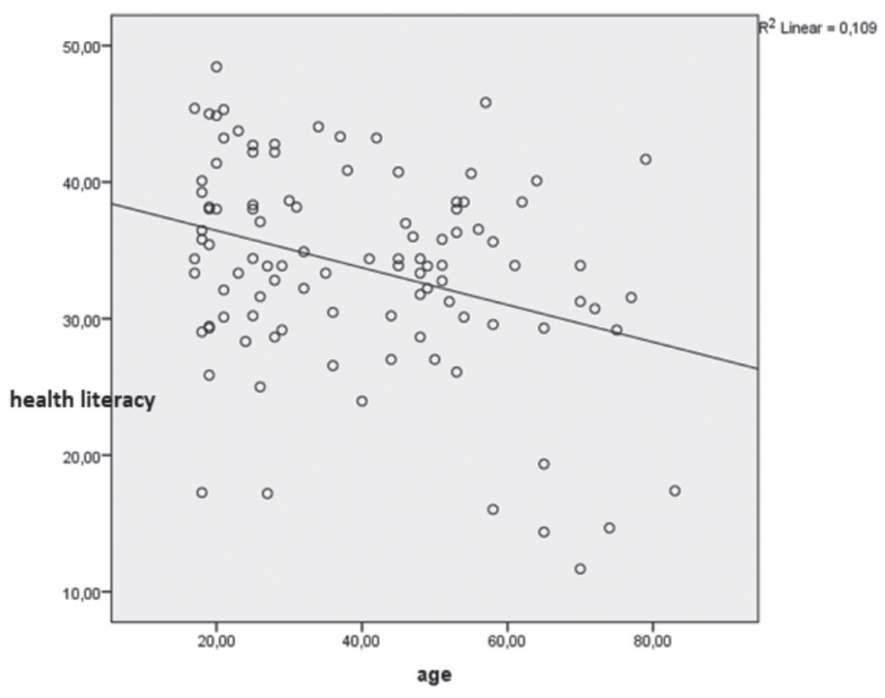

Graph 1. The scatter graph obtained from the analysis of the correlation between the Literacy index and age distribution

understand, and interpret health-related information, it includes skills such as measuring blood glucose and using drugs regularly (6). About 80 million adults in the US have poor health literacy.

Low health literacy is a global problem. Health policy regulators develop policies to identify and address this problem. For this reason, in the United States, Health Literacy: A Prescription to End Confusion were presented by The Institute of Medicine in 2004; The 2010 reports of the National Action Plan to Improve Health Literacy were presented by the Department of Health and Human Services in $2010(7,8)$.

Turkey Health Literacy Survey was conducted by Sağlık ve Sosyal Hizmet Çalışanları Sendikası in 2014. In this study, has revealed that one third of the adult population of Turkey in poor or problematic health literacy category (9). In our study, this rate was found as $57.9 \%$. We think that this rate caused by the fact that the health literacy levels of the patients admitted to the emergency department green area of our study population were lower than the normal population (10). In their study, Schumacher et al. (11) showed that it was related to health literacy in the emergency department and inability to access primary health care services.

Turkey Reliability and Validity of the Health Literacy scale was made by the Ministry of Health in order to develop a scale for Turkish society and to reveal the validity of health literacy scales in 2016. In our study, Turkey Health Literacy Scale-32 was used, the results of this research, which set forth the validity of the Turkish society.

Effective health care is associated with proper understanding of health information, regular health checks, and appropriate treatment $(11,12)$. In their study, Derose et al. (13) found that 
women with inadequate health literacy were less satisfied than emergency doctors than women with higher health literacy skills. There is a strong relationship between patient satisfaction and compliance in physicians. Therefore, we think that if the level of health literacy increases, patient satisfaction and patient compliance with medical advice will increase.

\section{Study Limitations}

In our study, we could not determine whether the severity of the disease changed according to the level of health literacy because the patients with the yellow and red triage who needed intervention due to health problems (e.g. hemodynamic instability, respiratory failure) or with high risk status evaluated by the nurse(changing mental state, severe pain or distress), were not included. Secondly, our study is a single-center study. Multicenter studies are needed.

\section{Conclusion}

As a conclusion; In our study, health literacy levels of patients who applied to emergency department with green triage code were found to be poor. This indicates the need for more attention to health promotion programs and health education.

\section{Ethics}

Ethics Committee Approval: The ethical committee approval of our study was obtained from the Ethical Committee of Clinic Researches of İstanbul Ümraniye Training and Research Hospital (approval number: 2018/153).

Informed Consent: Informed consent was obtained.

Peer-review: Internally and externally peer-reviewed.

\section{Authorship Contributions}

Concept: S.Ö., H.Ş.A., Design: S.Ö., H.Ş.A., Data Collection or Processing: S.Ö., H.Ș.A, A.A., K.K., Analysis or Interpretation: S.Ö., H.S..A, A.A., K.K., Literature Search: S.Ö., A.A., K.K., Writing: S.Ö., A.A.
Conflict of Interest: No conflict of interest was declared by the authors.

Financial Disclosure: The authors declared that this study received no financial support.

\section{References}

1. Nielsen-Bohlman L, Panzer AM, Kindig DA, editors. Health literacy: A Prescription to End confusion. 2004, Washington DC: The National Academies. DOI: 10.17226/10883

2. McNaughton C, Wallston KA, Rothman RL, Marcovitz DE, Storrow AB. Short, subjective measures of numeracy and general health literacy in an adult emergency department. Acad Emerg Med. 2011;18:1148-55.

3. Wolf MS, Gazmararian JA, Baker DW. Health literacy and functional health status among older adults. Arch Intern Med. 2005;165:1946-52.

4. Lindau ST, Tomori C, McCarville MA, Bennett CL. Improving rates of cervical cancer screening and Pap smear follow-up for low-income women with limited health literacy. Cancer Invest. 2001;19:316-23.

5. Baker DW, Gazmararian JA, Williams MV, Scott T, Parker RM, Green D, et al. Health literacy and use of outpatient physician services by Medicare managed care enrollees. J Gen Intern Med. 2004;19:215-20.

6. Berkman ND, Sheridan SL, Donahue KE, Halpern DJ, Crotty K. Low health literacy and health outcomes: an updated systematic review. Ann Intern Med. 2011;155:97-107.

7. Institute of Medicine. Report Brief. Health Literacy: A Prescription to End Confusion. Washington, DC: National Academies Pr; 2004.

8. U.S. Department of Health and Human Services, Office of Disease Prevention and Health Promotion. National Action Plan to Improve Health Literacy. Washington, DC: U.S. Department of Health and Human Services; 2010.

9. Durusu Tanrıöver M, Yıldırım HH, Demiray Ready FN, Çakır B, Akalın HE. Türkiye Sağlık Okuryazarlığı Araștırması. Sağık ve Sosyal Hizmet Çalışanları Sendikasl; Ankara, 2014 December. Available from: http://www.sagliksen. org.tr/cdn/uploads/gallery/pdf/8dcec50aa18c21cdaf86a2b33001a409.pdf

10. Okyay P, Abacıgil F. Türkiye Sağlık Okuryazarlığı Ölçekleri Güvenilirlik ve Geçerlilik Çalışması. Anıl Matbaa.1. Baskı. Ankara 2016; 43-60.

11. Schumacher JR, Hall AG, Davis TC, Arnold CL, Bennett RD, Wolf MS, et al. Potentially preventable use of emergency services: the role of low health literacy. Med Care. 2013;51:654-8.

12. Lee DS, Stukel TA, Austin PC, Alter DA, Schull MJ, You JJ, et al. Improved outcomes with early collaborative care of ambulatory heart failure patients discharged from the emergency department. Circulation. 2010;122:1806-14.

13. Derose KP, Hays RD, McCaffrey DF, Baker DW. Does Physician Gender Affect Satisfaction of Men and Women Visiting the Emergency Department? J Gen Intern Med. 2001;16:218-26. 